IOS Press

\title{
Meristem culture for the elimination of the strawberry crown rot pathogen Phytophthora cactorum
}

\author{
A.B. Whitehouse*, C.L. Govan, K.J. Hammond, D.J. Sargent and D.W. Simpson \\ East Malling Research, West Malling, Kent, UK
}

Received 26 November 2010; accepted 2 March 2011

\begin{abstract}
Two methods to induce a symptomless infection of crown rot (Phytophthora cactorum) in stolons of three strawberry (Fragaria $\times$ ananassa) cultivars were evaluated. Spraying a $10^{-4} \mathrm{ml}$ zoospore suspension was the most effective method, producing a mean infection rate of $12 \%$. Meristem cultures were subsequently established from all of the inoculated stolons and tested eight weeks later for the presence of P. cactorum using a PCR-based assay. A total of 784 meristems were excised and DNA was successfully extracted from 505 viable meristem cultures, 46 of which had been excised from stolons that were shown to have a symptomless infection of crown rot. No viable meristems were found to be infected with the pathogen. This investigation confirmed the suitability and reliability of meristem culture for the production of strawberry plants free from crown rot.
\end{abstract}

Keywords: Fragaria $\times$ ananassa, micropropagation, tissue culture, disease

\section{Introduction}

Phytophthora cactorum (Lebert and Cohn) Schröt. is a major plant pathogen affecting a number of globally important commercial species. In the cultivated strawberry (Fragaria $\times$ ananassa), it causes leather rot on fruit [14] and crown rot and wilt of plants [23]. The pathogen also has the ability to form latent or symptomless infection in plants, especially in propagation material, which is believed to have aided the dissemination of the disease throughout Europe $[6,10]$.

Micropropagation is used commercially for mass-producing strawberry plants [3] and meristem culture, which is often used to initiate micropropagation cultures, has proved effective in eliminating fungal pathogens and viruses in strawberries $[11,15]$. This technique is routinely used to produce healthy mother plants for commercial propagators and for initial entry of new cultivars into plant health certification schemes [13], including the United Kingdom (UK) Plant Health Propagation Scheme. Recently in the UK (2005), propagation material of two new everbearing cultivars derived from micropropagation was found to be infected with crown rot. Subsequently, there were suggestions that the use of meristem culture to eliminate the pathogen from plant material was ineffective, despite strong evidence to the contrary from previous studies $[11,15]$.

Previous investigations relied on traditional diagnostic techniques based on morphological and physiological characters, but subsequently considerable progress has been made in the use of DNA-based methods. In particular, polymerase chain reaction (PCR) assays provide more rapid and sensitive tests for the identification of $P$. cactorum

*Corresponding author: A.B. Whitehouse, East Malling Research, New Road, East Malling, West Malling, Kent, ME19 6BJ, UK. Tel.: +44 0 1732523746; Fax: +44 0 1732849067; E-mail: adam.whitehouse@emr.ac.uk. 
in plant tissues [2, 5, 22]. Causin et al. [5] developed sequence characterised amplified region (SCAR) markers from a P. cactorum-specific Random Amplified Polymorphic DNA (RAPD) amplicons which were able to detect the presence of the pathogen in a range of host plant tissues, including Fragaria vesca. Detection proved possible when the pathogen host ratio was as little as 1:1000 and when the amount of pathogen DNA was as low as $6 \mathrm{pg}$.

Success in artificially infecting strawberry plants with crown rot has been achieved by spraying plants with a zoospore suspension $[1,7,17]$ and by immersion of roots in hydroponic [19] or nutrient film technique (NFT) systems [18]. These investigations were principally performed to screen plants for resistance to crown rot, thus allowing necrosis, wilting and death to occur. However the establishment of a symptomless infection of $P$. cactorum in strawberry stolons has proved more difficult, with Harris et al. [11] achieving a symptomless infection rate of $8.9 \%$ by spraying plantlets of susceptible cultivars with a zoospore suspension. Therefore the objective of this investigation was to determine if meristem culture was effective in eliminating $P$. cactorum from infected but symptomless strawberry plants, using a sensitive PCR-based assay to detect the presence or absence of the pathogen.

\section{Materials and methods}

\subsection{Plant material}

Runner plants of three strawberry (Fragaria $\times$ ananassa) cultivars that have shown susceptibility to $P$. cactorum were tested in all experiments: 'Elsanta' the UK industry standard short-day cultivar, 'Rosie' a short-day cultivar and 'Malling Pearl' an everbearing cultivar.

\subsection{Inoculation}

All experiments were performed using a mixture of two P. cactorum isolates: P412 and P413. P412 and P413 are known to be pathogenic to $F$. xananassa having been isolated in 2005 from infected plants of the cultivars 'Malling Pearl' and 'Malling Opal' respectively. Two inoculation methods were employed to determine the most effective method of establishing a symptomless infection in stolon tips.

\subsubsection{Spray method}

$10 \mathrm{~mm}$ discs were cut from the margins of actively growing cultures of $P$. cactorum on V8 agar. Discs were immersed in a non-sterile compost extract ( 21 distilled water drained through $50 \mathrm{~g}$ compost) and incubated for 2-3 $\mathrm{d}$ at $20^{\circ} \mathrm{C}$ in an illuminated incubator and a $10^{4}$ zoospores per $\mathrm{ml}$ suspension was produced following the method described by Harris [9]. Ten cold-stored runner plants of each cultivar were potted up into $9 \mathrm{~cm}$ pots using a standard compost mix. These plants were placed into a warm glasshouse $\left(22^{\circ} \mathrm{C}\right.$ day, $17^{\circ} \mathrm{C}$ night, and $16 \mathrm{~h}$ photoperiod) and the position of each plant was randomised. Plants were deblossomed at regular intervals and after 12 weeks all stolons produced were inoculated by spraying them with a suspension of $10^{4}$ zoospores per $\mathrm{ml}$ of $P$. cactorum following the method of Harris et al. [11]. Inoculated stolons were covered with a clear polythene sheet for $24 \mathrm{~h}$ to prevent zoospores drying out. Any visible effects of inoculation were recorded after seven days and 50, 49 and 51 stolons tips were removed from 'Elsanta', 'Malling Pearl' and 'Rosie' respectively in order to establish meristem cultures. Untreated controls were kept under the same glasshouse conditions but were physically separated from inoculated plants and sprayed with distilled water instead of inoculum.

\subsubsection{Nutrient film technique (NFT) method}

$10 \mathrm{~mm}$ discs were cut from the margins of actively growing cultures of $P$. cactorum on V8 agar. Disks were placed onto PDA medium and incubated for $7 \mathrm{~d}$ at $22^{\circ} \mathrm{C}$ in the dark, and then transferred to a $4^{\circ} \mathrm{C}$ dark fridge for $21 \mathrm{~d}$. Twenty-four hours before inoculation, the disks were placed at room temperature in the dark. A $10^{7}$ sporangia per $\mathrm{ml}$ suspension was then produced for use as the innoculum following the method of Harris [9]. Ten cold-stored runner plants of each cultivar had their roots wrapped in rockwool blocks and were then placed into a nutrient film technique (NFT) system, as described by Parikka (2006) in a warm glasshouse $\left(22^{\circ} \mathrm{C}\right.$ day, $17^{\circ} \mathrm{C}$ night, and $16 \mathrm{~h}$ photoperiod). The position of each plant was randomised and the roots of the plants were immersed in a circulating 
nutrient solution (Solufeed H, Solufeed Ltd, West Sussex, UK). A suspension of $500 \mathrm{ml}$ of $10^{7}$ sporangia per ml of $P$. cactorum was then added to 801 of nutrient solution at the stage when stolons started to emerge. Any visible effects of infection were recorded after $14 \mathrm{~d}$, and 45, 48 and 100 stolons tips were removed from 'Elsanta', 'Malling Pearl' and 'Rosie' respectively in order to establish meristem cultures. Untreated controls were maintained in the same glasshouse compartment but were isolated in a separate, non-inoculated channel within the NFT system.

The most effective method of inoculation was identified by isolating tissue from directly beneath each dissected meristem and testing it for the presence of $P$. cactorum using the PCR-based method described later in this section. The inoculation method that gave the highest incidence of symptomless infection was identified and used to inoculate a further 146, 139 and 156 stolon tips of 'Elsanta', 'Malling Pearl' and 'Rosie' respectively.

\subsection{Excision of apical meristem}

Inoculated stolons were washed under running tap water prior to dissection. A single apical meristem $(0.2-0.5 \mathrm{~mm}$ in size) was dissected from each individual stolon and placed onto a strawberry initiation medium (SMI). SMI consisted of basal mineral salts medium [16] with $30 \mathrm{~g}$ sucrose, $0.1 \mathrm{~g}$ inositol, $0.5 \mathrm{mg}$ nicotinic acid, $0.5 \mathrm{mg}$ pyroxidine-HCl, $0.1 \mathrm{mg}$ thiamine, $1.0 \mu \mathrm{M}$ 6-benzylaminopurine, $0.5 \mu \mathrm{M}$ indole-3-butyric acid and $7.5 \mathrm{~g}$ Oxoid agar No. 3 per litre. All procedures were carried out aseptically and cultures were examined weekly for any microbial growth. Meristem cultures were maintained in a growth room $\left(22^{\circ} \mathrm{C}\right.$ and 16 hour photoperiod) for eight weeks and any viable cultures were then frozen using liquid nitrogen and stored at $-80^{\circ} \mathrm{C}$ until DNA extractions were performed.

\subsection{Dissection of sub-crown tissue}

The outer surface of the stolon was removed immediately after the apical meristem was excised and prior to the dissection of the sub-crown tissue to eliminate the risk of inoculated tissue contaminating the sample. A section of tissue measuring 5-10 $\mathrm{mm}$ was then removed using a sterile scapel blade from an area directly below the excision point of the meristem. This sub-crown tissue was frozen using liquid nitrogen and stored at $-80^{\circ} \mathrm{C}$ until DNA extractions were performed.

\subsection{DNA extraction from strawberry tissue}

All DNA was extracted using the DNeasy plant DNA miniprep extraction kits (Qiagen) following the manufacturer's protocols. For a positive control, DNA was extracted from a single plate of Phytophthora mycelium that was scraped into a $2 \mathrm{ml}$ microcrentrifuge tube, snap-frozen and ground with two ball-bearings, then extracted following the plant tissue protocol using the plant miniprep extraction kit for individual samples. Phytophthora DNA stock was diluted 1:50 for use in PCR. DNA was extracted from sub-crown tissue using the high-throughput DNeasy 96 extraction miniprep kit (96 samples simultaneously) and extractions were subsequently diluted 1:20 for use in PCR. DNA from meristems of samples testing positive for Phytophthora contamination in sub-crown tissue were extracted using the individual DNeasy plant miniprep extraction kit and diluted 1:50 for PCR. For meristems from those samples that tested negative for Phytopthora contamination, DNA was extracted using the DNeasy 96 miniprep kit and stocks were diluted 1:20 for subsequent use in PCR.

\subsection{PCR analysis}

All PCRs were performed in a final reaction volume of $12.5 \mu$ l comprising $2 \mu l$ template DNA, $1 \times$ PCR buffer, $1.5 \mathrm{mM} \mathrm{Mg}^{2+}, 200 \mu \mathrm{M}$ dNTPs, $0.2 \mu \mathrm{M}$ each primer and $0.25 \mathrm{U}$ Taq polymerase (Invitrogen). Fragaria genomic DNA was amplified as a positive internal control to indicate that PCR amplification had been successful. This was achieved using primer pair EMFxaDFR2 [21] (EMFxaDFR2F: 5'-caccggagtgttcatgtcg-3' EMFxaDFR2 R: 5' aacctccgaactgtctttgc-3'). PCR products were amplified using the touchdown protocol of Sargent et al. [20] in a final reaction volume of $12.5 \mathrm{ul}$ : an initial denaturation step of $94^{\circ} \mathrm{C}(2 \mathrm{~m})$, then 10 cycles of $94^{\circ} \mathrm{C}(30 \mathrm{~s}), 55-50^{\circ} \mathrm{C}$ annealing temperature decreasing by $0.5^{\circ} \mathrm{C}$ per cycle $(45 \mathrm{~s})$ and $72^{\circ} \mathrm{C}(1 \mathrm{~m})$, followed by 25 cycles of $94^{\circ} \mathrm{C}(30 \mathrm{~s}), 50^{\circ} \mathrm{C}(45 \mathrm{~s})$ 
and $72^{\circ} \mathrm{C}(1 \mathrm{~m})$, and a final elongation step of $72^{\circ} \mathrm{C}(5 \mathrm{~m})$. For the amplification of Phytophthora DNA from Fragaria tissue samples, DNA primers Phy1 (5'-ttccacgtgaaccgtatcaa-3') and Phy2 (5'-tgttcagccgaagccaacca- $\left.3^{\prime}\right)$ were used $(\mathrm{G}$. Down, personal communication). PCR products were amplified using the following protocol: an initial denaturation step of $94^{\circ} \mathrm{C}(2 \mathrm{~min})$, then 35 cycles of $94^{\circ} \mathrm{C}(30 \mathrm{~s}), 58^{\circ} \mathrm{C}(45 \mathrm{~s})$ and $72^{\circ} \mathrm{C}(1 \mathrm{~m})$, and a final elongation step of $72^{\circ} \mathrm{C}$ $(10 \mathrm{~m})$. PCR products amplified using each set of primer pairs were mixed together and co-loaded onto a $1.2 \%(\mathrm{w} / \mathrm{v})$ TAE agarose gel. Products were electrophoresed at $110 \mathrm{~V}$ for $2 \mathrm{~h}$ and visualised over UV light following staining in ethidium bromide solution $(0.5 \mu \mathrm{g}$ per $\mathrm{ml})$.

\section{Results and discussion}

\subsection{Inoculation of stolons}

The results of all the inoculation experiments are summarized in Table 1. Plants and stolons of 'Malling Pearl' and 'Rosie' taken from both the spray and NFT inoculation experiments were healthy in appearance, with no evidence of necrosis, at 7 and 14 days after infection. However plants and stolons of 'Elsanta' showed symptoms of powdery mildew (Podosphaera aphanis) in both experiments, although no necrosis or wilting was observed.

\subsubsection{Spray method}

Sub-crown tissue was successfully dissected from 50, 49 and 51 stolons of 'Elsanta', 'Malling Pearl' and 'Rosie' respectively. The percentage of samples testing positive for $P$. cactorum was calculated using the number of samples where extraction of Fragaria genomic DNA was successful, i.e. those extractions from which an amplicon was produced by PCR using the EMFxaDFR2 primer pair. The zoospore spray method was successful in inducing a symptomless infection rate of 5, 18 and 26\% in stolons of 'Elsanta', 'Malling Pearl' and 'Rosie' respectively, representing an overall mean infection rate of $16 \%$.

\subsubsection{Nutrient film technique (NFT) method}

Sub-crown tissue was successfully dissected from 48, 45 and 100 stolons of 'Elsanta', 'Malling Pearl' and 'Rosie' respectively. The NFT method was successful in inducing a symptomless infection rate of 0,21 and $7 \%$ in stolons of 'Elsanta', 'Malling Pearl' and 'Rosie' respectively, giving an overall mean infection rate of 9\%. All controls were found to be free of the pathogen. Comparing the susceptibility of cultivars to P. cactorum was not an objective of this investigation, but it was noted that the ranking of susceptibility was found to be different depending on the inoculation

Table 1

Results of inoculating stolon tips with Phytophthora cactorum

\begin{tabular}{|c|c|c|c|c|}
\hline \multirow[t]{2}{*}{ Cultivar } & \multirow[t]{2}{*}{ Method } & \multicolumn{3}{|c|}{ Numbers of sub-crown tissue samples } \\
\hline & & Total dissected & Yielding DFR $^{\mathrm{a}}$ & Yielding $P$. cactorum \\
\hline \multirow[t]{3}{*}{ Elsanta } & Spray & $50(9)^{\mathrm{b}}$ & $38(0)$ & $2(0)$ \\
\hline & NFT & $48(6)$ & $36(0)$ & $0(0)$ \\
\hline & Large-scale spray & $146(6)$ & $112(5)$ & $18(0)$ \\
\hline \multirow[t]{3}{*}{ Malling Pearl } & Spray & $49(9)$ & $40(9)$ & $7(0)$ \\
\hline & NFT & $45(6)$ & $33(6)$ & $7(0)$ \\
\hline & Large-scale spray & $139(5)$ & $41(3)$ & $2(0)$ \\
\hline \multirow[t]{3}{*}{ Rosie } & Spray & $51(9)$ & $46(9)$ & $12(0)$ \\
\hline & NFT & $100(6)$ & $57(4)$ & $4(0)$ \\
\hline & Large-scale spray & $156(8)$ & $120(5)$ & $12(0)$ \\
\hline Totals & & $784(64)$ & $523(41)$ & $64(0)$ \\
\hline
\end{tabular}

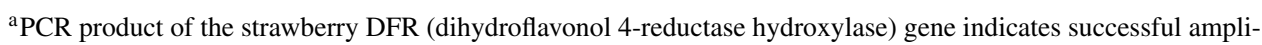

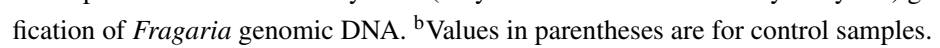


method used, which concurs with previous work where the variation in levels of resistance for a particular cultivar between the two systems was noted [18].

\subsubsection{Large scale inoculation using spray method}

Inoculation using the spray method resulted in the highest infection rate and was found to be the most practical. Therefore a second, larger scale, inoculation using the spray method was performed and sub-crown tissue was successfully dissected from a further 146 'Elsanta', 139 'Malling Pearl and 156 'Rosie' stolons. Plants and stolons of all three cultivars appeared healthy, with no evidence of necrosis, seven days after inoculation. A symptomless infection was induced in 16, 5 and 10\% of stolons of 'Elsanta', 'Malling Pearl' and 'Rosie' respectively; representing an overall mean infection rate of $12 \%$, lower than had been achieved in the smaller-scale experiment.

In summary 784 stolons were inoculated in all experiments, although DNA extraction was only successful from $523(67 \%)$ of the samples. The failure of DNA to be extracted from $33 \%$ of the samples may have been due to infection-induced phenolics which might indicate an underestimation of infection rates. A total of sixty-four (13\%) stolons derived from both inoculation methods, from which DNA was successfully extracted were found to have a symptomless infection of $P$. cactorum (Table 1), which represents a higher rate of symptomless infection than was achieved by Harris et al. [11] (8.9\%). All untreated (control) treatments tested negative for P. cactorum. Although the PCR was not species species-specific it has been assumed throughout that the PCR products produced were of $P$. cactorum due to the inoculation of the plant material with this species of the pathogen

\subsection{Meristem cultures}

The viability of meristem cultures eight weeks after excision are shown in Table 2 and a summary of the results of PCR analysis from viable meristems is shown in Table 3.

\subsubsection{Meristems derived from the spray method}

One hundred and fifty apical meristems were excised and appeared healthy at the time of excision, but subsequently a proportion failed to establish on SMI medium or were discarded due to microbial contamination (Table 2). In total, $96 \%$ of meristem cultures of 'Elsanta' were discarded either due to microbial contamination or failure to establish on SMI medium. This was also observed with meristems taken from untreated (control) stolons suggesting a cultivar specific factor rather than experimental or operator error. The presence of powdery mildew (Podosphaera aphanis) on the stolons may have hampered the establishment of meristems in culture, although this was unlikely to be a cause of contamination on the medium, as powdery mildew is an obligate fungus [4] and therefore is unlikely to grow on micropropagation media. Contaminants were comprised of a miscellaneous collection of fungi, bacteria and yeasts,

Table 2

Status of meristem cultures eight weeks after excision

\begin{tabular}{|c|c|c|c|c|c|}
\hline \multirow[t]{2}{*}{ Cultivar } & \multirow[t]{2}{*}{ Method } & \multicolumn{4}{|c|}{ Numbers of meristems } \\
\hline & & Total excised & Visibly contaminated & Failing to grow & Apparently healthy \\
\hline \multirow[t]{3}{*}{ Elsanta } & Spray & $50(9)^{\mathrm{a}}$ & $34(8)$ & $14(1)$ & $2(0)$ \\
\hline & NFT & $48(6)$ & $29(3)$ & $18(3)$ & $1(0)$ \\
\hline & Large-scale spray & $146(6)$ & $16(2)$ & $39(1)$ & $91(3)$ \\
\hline \multirow[t]{3}{*}{ Malling Pearl } & Spray & $49(9)$ & $0(0)$ & $5(0)$ & $44(9)$ \\
\hline & NFT & $45(6)$ & $5(0)$ & $0(0)$ & $40(6)$ \\
\hline & Large-scale spray & $139(5)$ & $0(0)$ & $13(1)$ & $126(4)$ \\
\hline \multirow[t]{3}{*}{ Rosie } & Spray & $51(9)$ & $2(0)$ & $1(0)$ & $48(9)$ \\
\hline & NFT & $100(6)$ & $10(2)$ & $2(0)$ & $88(4)$ \\
\hline & Large-scale spray & $156(8)$ & $32(3)$ & $22(0)$ & $102(5)$ \\
\hline Totals & & $784(64)$ & $128(18)$ & $114(6)$ & $542(40)$ \\
\hline
\end{tabular}

${ }^{a}$ Values in parentheses are for control samples. 
Table 3

Summary of results from viable meristems eight weeks after excision

\begin{tabular}{|c|c|c|c|c|}
\hline \multirow[t]{2}{*}{ Cultivar } & \multirow[t]{2}{*}{ Method } & \multicolumn{3}{|c|}{ Numbers of meristems } \\
\hline & & Apparently healthy & Yielding DFR $^{\mathrm{a}}$ & Yielding $P$. cactorum \\
\hline \multirow[t]{3}{*}{ Elsanta } & Spray & $2(0)^{\mathrm{b}}$ & $2(0)$ & $0(0)$ \\
\hline & NFT & $1(6)$ & $1(0)$ & $0(0)$ \\
\hline & Large-scale spray & $91(3)$ & $82(3)$ & $0(0)$ \\
\hline \multirow[t]{3}{*}{ Malling Pearl } & Spray & $44(9)$ & $43(9)$ & $0(0)$ \\
\hline & NFT & $40(6)$ & $38(6)$ & $0(0)$ \\
\hline & Large-scale spray & $126(4)$ & $118(4)$ & $0(0)$ \\
\hline \multirow[t]{3}{*}{ Rosie } & Spray & $48(9)$ & $48(9)$ & $0(0)$ \\
\hline & NFT & $88(4)$ & $83(4)$ & $0(0)$ \\
\hline & Large-scale spray & $102(5)$ & $90(5)$ & $0(0)$ \\
\hline Totals & & $542(46)$ & $505(40)$ & $0(0)$ \\
\hline
\end{tabular}

a PCR product of the strawberry DFR (dihydroflavonol 4-reductase hydroxylase) gene indicates successful amplification of Fragaria genomic DNA. ${ }^{b}$ Values in parentheses are for control samples.

however there was no evidence of contamination with $P$. cactorum. Of 93 successful DNA extractions from viable meristem cultures, including 17 taken from stolons testing positive for $P$. cactorum, none was found to be infected with the pathogen (Table 3 ).

\subsubsection{Meristems derived from the nutrient film technique (NFT) method}

All apical meristems appeared healthy at the time of dissection. Ninety-eight percent of 'Elsanta' meristems were discarded either due to microbial contamination or failure to establish on SMI medium. Of the 122 successful extractions taken from viable meristem cultures, including 11 taken from stolons testing positive for P. cactorum, none was found to be infected with the pathogen.

\subsubsection{Large scale inoculation using spray method}

Meristems taken from stolons of 'Elsanta' and 'Malling Pearl' appeared healthy at the time of excision; however 12 meristems excised from stolons of 'Rosie' were found to be necrotic. These meristems were not included in the main experiment but were nevertheless placed on SMI medium. All necrotic meristems failed to develop, and a white fungal growth appeared on the surface of the medium after seven days. A sample of the contaminant was plated out onto a selective medium [12] and was confirmed to be $P$. cactorum. The high incidence of microbial contamination observed in cultures derived from stolons of 'Elsanta' in the previous experiments was not apparent in this experiment, although no explanation for this difference is obvious. Of 290 successful extractions taken from viable meristems, including 18 taken from stolons testing positive for $P$. cactorum, none were found to be infected with the pathogen.

In total, 547 viable meristems were produced from the 784 stolons that were inoculated with $P$. cactorum, representing a mean survival rate of $65 \%$. DNA was successfully extracted from 505 (92\%) viable meristem cultures but none was found to be infected with $P$. cactorum, including 46 samples taken from stolons that were known have a symptomless infection of the disease.

Although the percentage of symptomless infection achieved in this investigation was low, it represents a higher rate of infection than reported by Harris et al. [11]. This is most probably due to the greater sensitivity of the PCR method in detecting the presence of $P$. cactorum. No necrosis was observed on any inoculated stolons although stolons were harvested a short time after inoculation and symptoms of infection may have appeared had a longer period after inoculation been observed. This experiment simulated a situation where infected, but apparently healthy stolons might be used to establish meristem cultures. The presence of $P$. cactorum in the stolons of plants infected using the NFT method after 14 days suggested that a root infection by the pathogen can rapidly spread to other tissue, including stolons that are routinely used for the vegetative propagation of strawberry material. Erwin and Ribeiro [8] 
reported that $P$. fragariae, the causative pathogen of red core disease in strawberry, was capable of infecting xylem tissue, suggesting a possible route of systemic infection.

\section{Conclusion}

In this paper, we have reported the application of a PCR-based method for the detection of the pathogen $P$. cactorum in stolon and meristem-derived tissue of the cultivated strawberry $F . \times$ ananassa. Stolons inoculated with zoospores of the pathogen by both a spray method and by the nutrient film technique were shown to become infected with $P$. cactorum, which was readily detected by PCR. However, when DNA was extracted from micropropagated cultures derived from meristems excised from these stolons, and grown for eight weeks on strawberry initiation medium, no pathogen could be detected in any of the samples tested. The absence of a Phytophthora PCR product in the meristem where the assay was positive in the associated crown tissue is strongly supportive that meristem culture is an effective method of removing the pathogen. We can conclude that meristem culture was effective in eliminating P. cactorum from stolons that had a symptomless infection, supporting the findings of Harris et al. [11] and Molot et al. [15].

\section{Acknowledgments}

Financial support for this work was provided by the Horticultural Development Council, Meiosis Ltd. and the Nuclear Stock Association.

\section{References}

[1] J.A. Bell, D.W. Simpson and D.C. Harris, Development of a method for screening strawberry germplasm for resistance to Phytophthora cactorum, Acta Horticulturae 439 (1997), 175-179.

[2] R.G. Bhat and G.T. Browne, Development of an improved PCR-based technique for detection of Phytophthora cactorum in strawberry plants, Phytopathology 97 (2007), Suppl. S, S10.

[3] P. Boxus, Review on strawberry mass propagation, Acta Horticulturae 265 (1989), 309-320.

[4] D.J. Butt, Epidemiology of Powdery Mildews, in: The Powdery Mildews, D.M. Spencer, ed., Academic Press Inc., London, 1978, pp. 51-81.

[5] R. Causin, C. Scopel, A. Grendene and L. Montecchio, An improved method for the detection of Phytophthora cactorum (LC) Schroeter in infected plant tissue using SCAR markers, Journal of Plant Pathology 87 (2005), 25-35.

[6] B. De los Santos, M. Porras, C. Blanco, C. Barrau and F. Romero, First report of Phytophthora cactorum on strawberry plants in Spain, Plant Disease 86 (2002), 1051.

[7] H. Eikemo, A. Stensvand and A.M. Tronsmo, Evaluation of methods of screening strawberry cultivars for resistance to crown rot caused by Phytophthora cactorum. Annals of Applied Biology 137 (2000), 237-244.

[8] D.C. Erwin and O.K. Ribeiro, Phytophthora diseases worldwide, American Phytopathological Society Press, St. Paul, Minnesota, USA, 1996 , p. 25

[9] D.C. Harris, Methods for preparing, estimating and diluting suspensions of Phytophthora cactorum zoospores, Transactions of the British Mycological Society 86 (1986), 482-486.

[10] D.C. Harris and J.E. Stickels, Crown rot (Phytophthora cactorum) in glasshouse-grown strawberries at East Malling Research Station, Plant Pathology 30 (1981), 205-212.

[11] D.C. Harris, D.W. Simpson and J.A. Bell, Studies on the possible role of micropropagation in the dissemination of the strawberry crown rot pathogen Phytophthora cactorum, Journal of Horticultural Science 72(1997), 125-133.

[12] M.E. Kannwischer and D.J. Mitchell, The influence of a fungicide on the epidemiology of black shank of tobacco, Phytopathology 2 (1978), $117-137$.

[13] R. Lines, G. Kelly, M. Milinkovic and B. Rodoni, Runner certification and virus elimination in commercial strawberry cultivars in Australia, Acta Horticulturae 708 (2006), 253-254.

[14] J.L. Mass, Compendium of Strawberry Diseases. American Phytopathological Society Press, St. Paul, Minnesota, USA, 1984.

[15] P.-M. Molot, J.P. Leroux and J.-G. Nourrisseau, Régénération par culture d'apex de clones de fraisers infectés de façon chronique par le Phytophthora cactorum, Comptes Rendues de troisième Congrès U.P.M. Lisbon (1972), 415-419. 
[16] T. Murashige and F. Skoog, A revised medium for the rapid growth and bioassays with tobacco tissue cultures, Physiologia Plantarum 15 (1962), 473-497.

[17] P. Parikka, Disease resistance in strawberry breeding programmes - Major pathogens in European strawberry production, Acta Horticulturae 649 (2004), 49-53.

[18] P. Parikka, Screening for strawberry plant resistance to Phytophthora cactorum in a nutrient film technique (NFT) system, Acta Horticulturae 708 (2006), 119-122.

[19] P.C.L. van Rijbroek, E.J. van Meulenbrook and C.P.J. van de Lindeloof, Development of a screening method for resistance to Phytophthora cactorum, Acta Horticulturae 439 (1997), 181-183.

[20] D.J. Sargent, A.M. Hadonou and D.W. Simpson, Development and characterization of polymorphic microsatellite markers from Fragaria viridis, a wild diploid strawberry, Molecular Ecology Notes 3 (2003), 550-552.

[21] D.J. Sargent, A. Rys, S. Nier, D.W. Simpson and K.R. Tobutt, The development and mapping of functional markers in Fragaria and their transferability and potential for mapping in other genera, Theoretical and Applied Genetics 114 (2007), 373-384.

[22] L. Ward, P. Beales, G. Budge, A. Barnes and G. Downe, Development and evaluation of a real-time (TaqMan $\left.{ }^{\circledR}\right)$ PCR assay of or detection of Phytopthora cactorum (Crown rot) in Strawberry Tissue, Horticultural Development Council Final Report Project SF82 (2006).

[23] W.F. Wilcox, First report of crown rot (Phytophthora cactorum) of strawberry in Eastern America, Plant Disease 66 (1989), 183. 